Original Article

\title{
STABILITY INDICATING RP-HPLC ASSAY METHOD FOR ESTIMATION OF MIDODRINE HYDROCHLORIDE IN BULK AND TABLETS
}

\author{
HEMANT K. JAIN*, KISHOR N. GUJAR, VARSHA A. RANDHE \\ Department of Quality Assurance Techniques, Sinhgad College of Pharmacy, Vadgaon (Bk.), Pune (411041), Maharashtra, India \\ Email: hemantkjain2001@yahoo.co.in
}

Received: 22 Jun 2016 Revised and Accepted: 22 Jul 2016

\section{ABSTRACT}

Objective: To develop an accurate, simple, sensitive and precise stability indicating reverse phase-high performance liquid chromatographic (RPHPLC) assay method for estimation of Midodrine hydrochloride (MD) in bulk and tablets.

Methods: The chromatographic separation was performed on enable $\mathrm{C}_{18},(250 \mathrm{~mm} \mathrm{X} 4.6 \mathrm{~mm}, 5 \mu \mathrm{m})$ column. The mobile phase consists of triethylamine buffer $0.02 \%, \mathrm{pH}-3$ : acetonitrile $(38: 62 \mathrm{v} / \mathrm{v})$ was delivered at a flow rate of $0.6 \mathrm{ml} / \mathrm{min}$ and UV detection at $289 \mathrm{~nm}$. The method was validated with forced degradation studies as per ICH guidelines.

Results: The retention time of the drug was found to be $3.56 \mathrm{~min}$. The developed method was found to be linear in a concentration range of 19.98$99.9 \mu \mathrm{g} / \mathrm{ml}$ of the drug $\left(\mathrm{r}^{2}=0.9998\right)$. The low value of \% RSD indicates reproducibility of the method. The low value of LOD and LOQ suggests the sensitivity of the method. The results of forced degradation studies indicated that the drug was stable in acidic condition and degraded in basic, oxidative and hydrolytic conditions.

Conclusion: The present study represents first stability-indicating HPLC assay method that deals with the estimation of midodrine hydrochloride. It can be concluded from the results that the developed method is simple, rapid, accurate, specific, sensitive and precise. Thus, this method can be used for routine analysis of midodrine hydrochloride formulation and to check the stability of bulk samples.

Keywords: Midodrine hydrochloride, RP-HPLC, Method validation, Stability indicating assay method

(C) 2016 The Authors. Published by Innovare Academic Sciences Pvt Ltd. This is an open access article under the CC BY license (http://creativecommons. org/licenses/by/4. 0/) DOI: http://dx.doi.org/10.22159/ijpps.2016v8i9.13619

\section{INTRODUCTION}

Midodrine hydrochloride (MD) is chemically $( \pm)$-2-amino-N-( $\beta$ hydroxy-2, 5-dimethoxyphenethyl) acetamide monohydrochloride [1]. Midodrine is a prodrug, which forms an active metabolite desglymidodrine. Desglymidodrine is an alpha- 1 agonist, activates $\alpha$ adrenergic receptors of the arteriolar and venous vasculature that increases vascular tone and blood pressure [2]. This drug is official in United States Pharmacopeia (USP). Literature survey revealed that spectrophotometric methods for determination of midodrine hydrochloride [3, 4] and ion selective method [5] and HPLC [6]. Midodrine hydrochloride was also determined in plasma by HPLC method with fluorescence detection [7] and LC-MS/MS method [8] There has no stability-indicating HPLC assay method reported yet for estimation of midodrine hydrochloride in bulk and pharmaceutical formulation. Therefore, the present work involves the development of a stability indicating RP-HPLC assay method for estimation of this drug in bulk and tablets.<smiles>COc1ccc(OC)c(COC(N)=O)c1</smiles>

$\mathrm{HCl}$

Fig. 1: Chemical structure of midodrine hydrochloride

\section{MATERIALS AND METHODS}

Chemicals and reagents

Midodrine hydrochloride was purchased from Industriale Chimica SRL, Italy. Commercially available tablets (ProAmatine ${ }^{\circledR}: 2.5 \mathrm{mg}$ of midodrine hydrochloride) used in this study were purchased from local market. HPLC grade of solvents was procured from Loba Chemie Pvt. Ltd., Mumbai and AR grade of chemicals were obtained from Merck Pvt. Ltd., Mumbai.

\section{Instruments}

The method was performed on shimadzu (LC 2010 CHT, Japan) having a quaternary system with automatic injection facility and UVvisible detection system. The column 'enable' $\mathrm{C}_{18}$, LC solution software and shimadzu AY-120 balance were used for this work.

\section{Preparation of standard stock solution}

An accurately weighed quantity of drug midodrine hydrochloride equivalent to $100 \mathrm{mg}$ was transferred to $100 \mathrm{ml}$ volumetric flask. The drug was dissolved and diluted up to the mark with water.

\section{Assay of tablets}

Twenty tablets were weighed, and average weight was calculated. These tablets were crushed in a glass mortar. An accurately weighed $100 \mathrm{mg}$ drug was transferred to a $100 \mathrm{ml}$ of volumetric flask then diluted up to mark with water. The solution was filtered through whatman filter paper no. 41. This solution was further diluted to obtain $60 \mu \mathrm{g} / \mathrm{ml}$ solutions with water, and this procedure was repeated in triplicate $[9,10]$. The results of the assay of tablets are shown in table 2 .

\section{Validation of the method}

The developed chromatographic method was validated for system suitability, linearity, range, accuracy, precision and robustness parameters, as per ICH guidelines [11-14]

\section{Linearity and range}

Working standard solutions were injected under the optimized chromatographic conditions and peak areas were calculated at 289 nm. The calibration curve was plotted between areas against corresponding concentrations of the drug. Linear regression data for 
calibration curve was shown in fig. 3 . The range of solution has been decided according to a correlation coefficient of the regression equation.

\section{Precision}

Repeatability study was carried out with six replicates, and intermediate precision studies were carried out with three concentrations of midodrine hydrochloride with three replicates. The values of \% relative standard deviation (\% RSD) of precision study are shown in table 3 .

\section{Robustness}

Robustness of the optimized method was studied by changing flow rate $( \pm 0.1 \mathrm{ml} / \mathrm{min})$, change in wavelength $( \pm 2 \mathrm{~nm})$ and change in mobile phase composition $( \pm 5 \%)$ during analysis. The sample was injected in triplicate for every condition and \% RSD was calculated for each condition is shown in table 5 .

\section{Limit of detection (LOD) and limit of quantitation (LOQ)}

Five sets of concentrations were prepared between 19.98-99.90 $\mu \mathrm{g} / \mathrm{ml}$ and the corresponding areas of these sets were measured. Calibration curves were plotted for each set. The standard deviation of the y-intercept and average slope of the calibration curve was used to calculate LOD and LOQ using following formulae.

$$
L O D=\frac{3.3 \times \mathrm{SD}}{\mathrm{S}} L O Q=\frac{10 \times \mathrm{SD}}{\mathrm{S}}
$$

Where SD is the standard deviation of y-intercepts of the calibration curves; $\mathrm{S}$ is the mean slope of six calibration curves.

\section{Accuracy}

The accuracy of the method was determined by calculating percent recovery of the drug by standard addition method. Percent recovery of midodrine hydrochloride was determined at three different level $80 \%, 100 \%$, and $120 \%$ of the target concentration in triplicate. The results of accuracy study are shown in table 4 .

\section{Forced degradation studies}

To evaluate stability, midodrine hydrochloride was subjected to force degradation under the condition of acid, base, neutral hydrolysis and oxidation as per international conference on harmonization (ICH) guidelines [15]

\section{Alkaline hydrolysis}

$100 \mathrm{mg}$ of midodrine hydrochloride was weighed accurately and transferred in $250 \mathrm{ml}$ round bottom flask containing $100 \mathrm{ml}$ of $0.1 \mathrm{~N}$ sodium hydroxide $(\mathrm{NaOH})$. This mixture was refluxed at $80^{\circ} \mathrm{C}$. After every 30 min $5 \mathrm{ml}$ of refluxed sample was withdrawn and neutralized with $5 \mathrm{ml}$ of $0.1 \mathrm{~N}$ hydrochloric acid. This solution was further diluted 10 times with mobile phase to obtain a concentration of $100 \mu \mathrm{g} / \mathrm{ml}$. The chromatogram obtained after $2 \mathrm{~h}$ of alkali hydrolysis is shown in fig. $4 \mathrm{~A}$.

\section{Acid hydrolysis}

$100 \mathrm{mg}$ of midodrine hydrochloride was weighed accurately and transferred in $250 \mathrm{ml}$ round bottom flask containing $100 \mathrm{ml}$ of $0.1 \mathrm{~N}$ hydrochloric acid $(\mathrm{HCl})$. This mixture was refluxed at $80^{\circ} \mathrm{C}$. After every $30 \mathrm{~min} 5 \mathrm{ml}$ of refluxed sample was withdrawn and neutralized with $5 \mathrm{ml}$ of $0.1 \mathrm{~N}$ sodium hydroxide. This solution was further diluted 10 times with mobile phase to obtain a concentration of $100 \mu \mathrm{g} / \mathrm{ml}$. The chromatogram obtained after $2 \mathrm{~h}$ of acid hydrolysis is shown in fig. 4B.

\section{Oxidative degradation}

$100 \mathrm{mg}$ of midodrine hydrochloride was weighed accurately and transferred in $250 \mathrm{ml}$ round bottom flask containing $100 \mathrm{ml}$ of $30 \%$ hydrogen peroxide $\left(\mathrm{H}_{2} \mathrm{O}_{2}\right)$. This mixture was refluxed at $80^{\circ} \mathrm{C}$. After $30 \mathrm{~min} 5 \mathrm{ml}$ of refluxed sample was withdrawn. This solution was further diluted 10 times with mobile phase to obtain a concentration of $100 \mu \mathrm{g} / \mathrm{ml}$. The chromatogram obtained after $30 \mathrm{~min}$ of oxidative degradation is shown in fig. 4C.

\section{Hydrolytic degradation}

$100 \mathrm{mg}$ of midodrine hydrochloride was weighed accurately and transferred in $250 \mathrm{ml}$ round bottom flask containing $100 \mathrm{ml}$ water $\left(\mathrm{H}_{2} \mathrm{O}\right)$. This mixture was refluxed at $80^{\circ} \mathrm{C}$. After every $30 \mathrm{~min} 5 \mathrm{ml}$ of refluxed sample was withdrawn. This solution was further diluted 10 times with mobile phase to obtain a concentration of $100 \mu \mathrm{g} / \mathrm{ml}$. The chromatogram obtained after $2 \mathrm{~h}$ of hydrolytic degradation is shown in fig. 4D.

\section{RESULTS AND DISCUSSION}

\section{Selection of detection wavelength}

Detection wavelength of midodrine hydrochloride was selected as wavelength maxima ( $\lambda \max$ ) from UV absorption spectrum of the drug between $200-400 \mathrm{~nm}$. The value of $\lambda \max$ was found to be 289 nm.

\section{Optimization of chromatographic conditions}

Initially, various chromatographic conditions were tried in order to obtain better separation characteristics by changing mobile phase composition and $\mathrm{pH}$. Finally, mobile phase triethylamine buffer $0.02 \% \mathrm{v} / \mathrm{v}(\mathrm{pH}-3)$ : acetonitrile $(38: 62 \mathrm{v} / \mathrm{v})$ at the flow rate 0.6 $\mathrm{ml} / \mathrm{min}$ was selected with UV detection at $289 \mathrm{~nm}$. The retention time of midodrine hydrochloride was found to be $3.56 \mathrm{~min}$. indicated that the method is rapid. The chromatogram of midodrine hydrochloride is shown in fig. 2 and optimized chromatographical conditions are mentioned in table 1 .

Table 1: Optimized chromatographic conditions

\begin{tabular}{ll}
\hline Parameters & Details \\
\hline Mobile phase & Triethylamine buffer $0.02 \%(\mathrm{pH}-3):$ \\
& acetonitrile $(38: 62 \mathrm{v} / \mathrm{v})$ \\
Column & 'Enable' $\mathrm{C}_{18}, 250 \mathrm{~mm}$ X $4.6 \mathrm{~mm}, 5 \mu \mathrm{m}$ \\
Flow rate & $0.6 \mathrm{ml} / \mathrm{min}$ \\
Detection & UV at $289 \mathrm{~nm}$ \\
Injection volume & $20 \mu \mathrm{l}$ \\
Runtime & $15 \mathrm{~min}$ \\
Retention time & $3.564 \pm 0.02$ min. \\
Diluent & Triethylamine buffer $0.02 \%(\mathrm{pH}-3):$ \\
& acetonitrile $(38: 62 \mathrm{v} / \mathrm{v})$ \\
\hline
\end{tabular}

\section{Assay of tablet formulation}

The value of mean $\%$ drug found to be $98.70 \%$ which was within acceptance criteria.

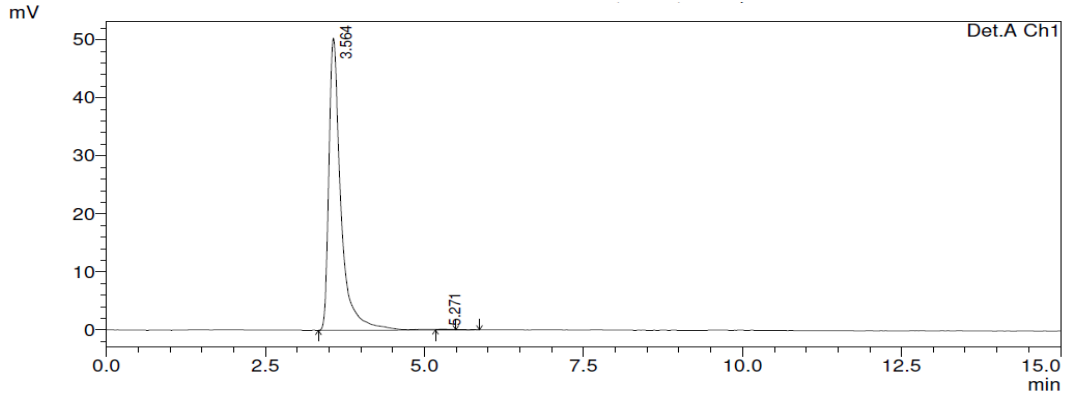

Fig. 2: Chromatogram of midodrine hydrochloride 
Table 2: Results of assay of midodrine hydrochloride

\begin{tabular}{llll}
\hline S. No. & Sample solution concentration $(\boldsymbol{\mu g} / \mathbf{m l})$ & Actual concentration found & Amount of drug estimated mean \pm SD \\
\hline 1 & 60 & 59.04 & $98.70 \pm 0.219$ \\
2 & 60 & 59.17 & \\
3 & 60 & 59.47 & \\
\hline
\end{tabular}

*The value is represented as a mean \pm SD of 3 observations.

Table 3: Repeatability and intermediate precision for midodrine hydrochloride

\begin{tabular}{lll}
\hline Precision & Concentration of drug $(\boldsymbol{\mu g} / \mathbf{m l})$ & Mean area $\mathbf{S}$ SD \\
\hline Repeatability $(\mathrm{n}=6)$ & 59.94 & $1793956 \pm 1901.33$ \\
Intra-day & 39.96 & $1204837 \pm 5773.62$ \\
(n=3) & 59.94 & $1787905 \pm 5884.4$ \\
& 79.92 & $2362555 \pm 2413.44$ \\
Inter-day & 39.96 & $1218635 \pm 5239.69$ \\
(n=3) & 59.94 & $1790171 \pm 10058.9$ \\
& 79.92 & $2191845 \pm 2872.63$ \\
\hline
\end{tabular}

*Each value is represented as a mean $\pm \mathrm{SD}$ of $\mathrm{n}$ observations. The value of $\mathrm{n}$ is 6 for repeatability study and 3 for intraday and interday precision. SD: Standard deviation, \%RSD: Percent relative standard deviation

Table 4: Recovery study for midodrine hydrochloride

\begin{tabular}{|c|c|c|c|c|}
\hline Levels & Amount taken $(\mu \mathrm{g} / \mathrm{ml})$ & Amount found $(\mu \mathrm{g} / \mathrm{ml})$ & \% recovery* & Mean \%recovery $\%$ RSD \\
\hline & & 46.60 & 97.08 & \\
\hline \multirow[t]{3}{*}{$80 \%$} & 48 & 46.62 & 97.09 & $97.08 \pm 0.006$ \\
\hline & & 46.59 & 97.07 & \\
\hline & & 58.88 & 98.14 & \\
\hline \multirow[t]{3}{*}{$100 \%$} & 60 & 59.02 & 98.37 & $98.25 \pm 0.032$ \\
\hline & & 58.95 & 98.25 & \\
\hline & & 71.17 & 98.85 & \\
\hline \multirow[t]{2}{*}{$120 \%$} & 72 & 71.24 & 98.95 & $98.94 \pm 0.091$ \\
\hline & & 71.31 & 99.04 & \\
\hline
\end{tabular}

*Percent recovery was done in triplicate, \% recovery: Percent recovery, \%RSD: Percent relative standard deviation

\section{Linearity and range}

The value of correlation coefficient for midodrine hydrochloride (fig. 3) demonstrated the good relationship between peak areas and concentrations. Therefore, the developed method was linear in the concentration range of 19.98-99.90 $\mu \mathrm{g} / \mathrm{ml}$.

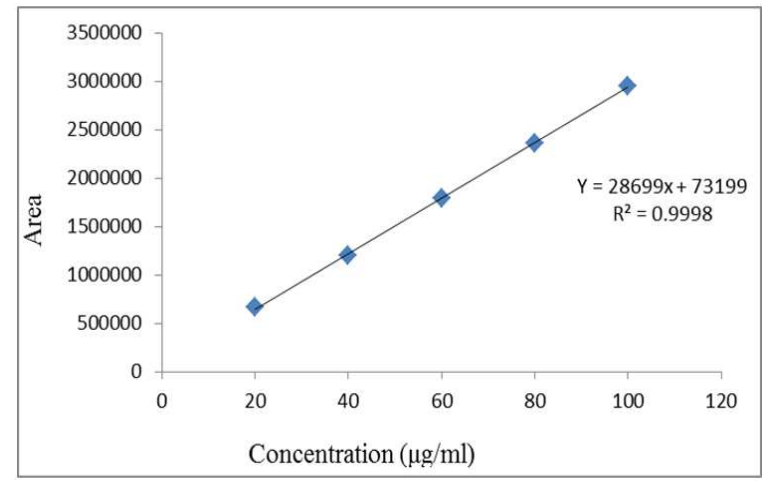

Fig. 3: Calibration curve of midodrine hydrochloride

\section{Precision}

The method is precise and the \%RSD values were within an acceptable limit.

\section{Accuracy}

The value of mean \% recovery and \% RSD at each level was found within acceptance criteria that indicate the method is accurate.

\section{Robustness}

The value of \% RSD was found to be within acceptance criteria which showed the reliability of the method.

Table 5: Robustness study for midodrine hydrochloride

\begin{tabular}{lc}
\hline Factor & \%RSD $^{*}$ \\
\hline A: Change in flow rate & \\
$0.8 \mathrm{ml} / \mathrm{min}$ & 0.014 \\
$0.9 \mathrm{ml} / \mathrm{min}$ & 0.023 \\
$1.0 \mathrm{ml} / \mathrm{min}$ & 0.018 \\
B: Change in wavelength & \\
$288 \mathrm{~nm}$ & 0.030 \\
$290 \mathrm{~nm}$ & 0.421 \\
$292 \mathrm{~nm}$ & 0.397 \\
C: Change in mobile phase composition & \\
Triethylamine Buffer: Acetonitrile (34:66) & 0.068 \\
Triethylamine Buffer: Acetonitrile (36:64) & 0.038 \\
Triethylamine Buffer: Acetonitrile (35:65) & 0.020 \\
\hline
\end{tabular}

*Each value is represented as \% RSD of $\mathrm{n}$ observations. The value of $\mathrm{n}$ is 3 for change in flow rate, change in wavelength and change in mobile phase composition. \%RSD: Percent relative standard deviation

\section{Limit of detection (LOD) and limit of quantitation (LOQ)}

The values of limit of detection and limit of quantification were found to be 2.43 and $7.41 \mu \mathrm{g} / \mathrm{ml}$; respectively that indicated the method is sensitive.

\section{Forced degradation studies}

Midodrine hydrochloride was degraded under different stress conditions like alkaline, acidic hydrolysis, oxidative degradation and hydrolytic degradation. 
$\mathrm{mV}$

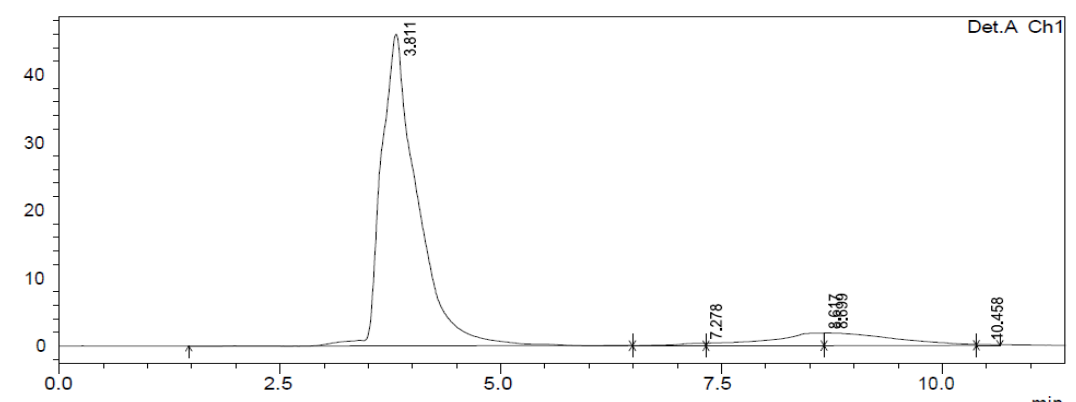

Fig. 4 (A)

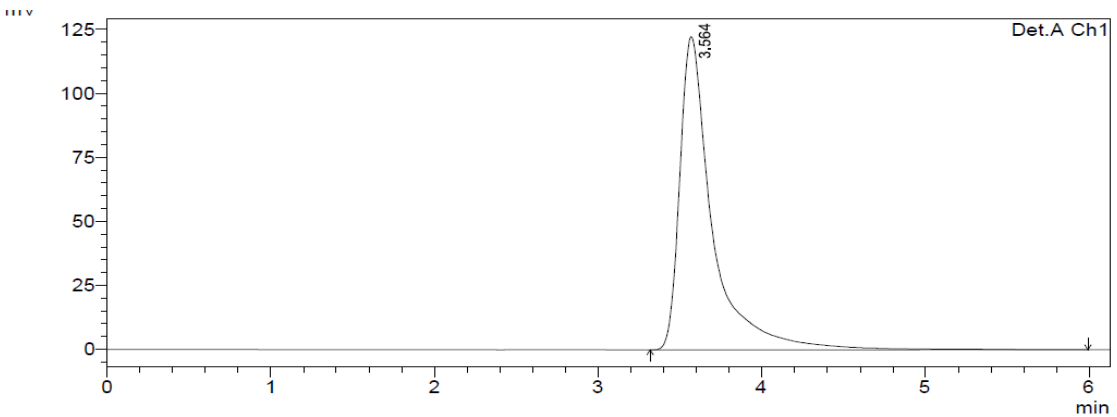

Fig. 4 (B)

$\mathrm{mV}$

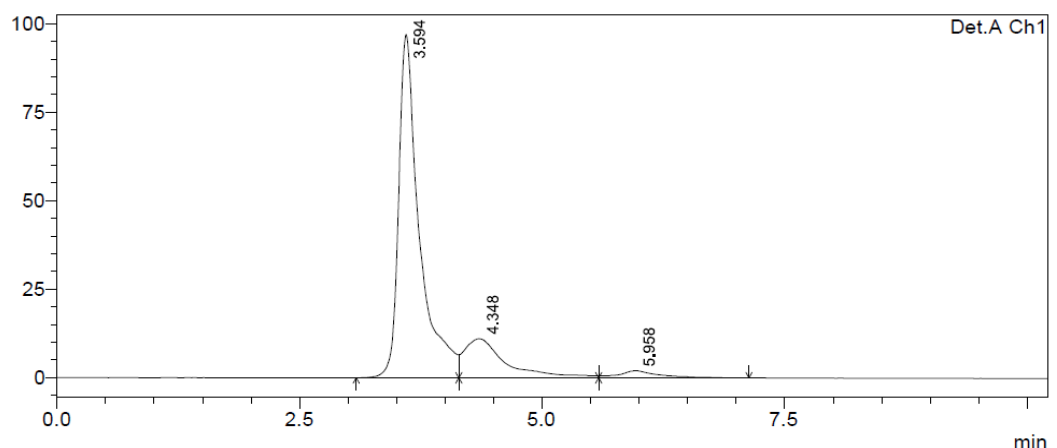

Fig. 4(C)

$\mathrm{m} v$

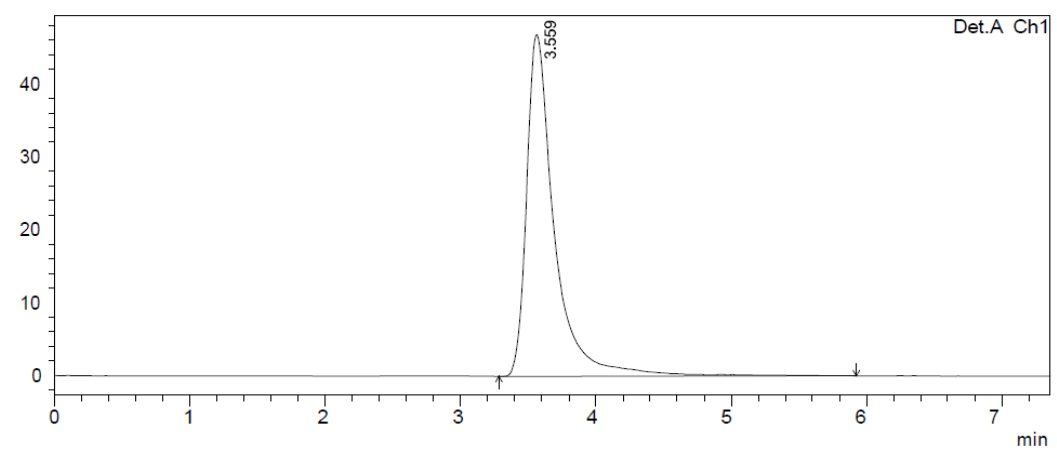

Fig. 4(D)

Fig. 4: Typically degradation chromatograms of midodrine hydrochloride; (A): in $0.1 \mathrm{~N} \mathrm{NaOH}$ at $80{ }^{\circ} \mathrm{C}$ after $2 \mathrm{~h}$. (B): in $0.1 \mathrm{~N} \mathrm{HCl}$ at $80{ }^{\circ} \mathrm{C}$ after $2 \mathrm{~h}$. (C): in $30 \% \mathrm{H}_{2} \mathrm{O}_{2}$ at $80{ }^{\circ} \mathrm{C}$ after $30 \mathrm{~min}$. (D): in water at $80{ }^{\circ} \mathrm{C}$ after $2 \mathrm{~h}$

Initially, $0.1 \mathrm{~N} \mathrm{NaOH}$ solution was used for degradation of midodrine hydrochloride at $80^{\circ} \mathrm{C}$ for $30 \mathrm{~min}$ but there was no degradation. So same solution was further used at $80{ }^{\circ} \mathrm{C}$ for $2 \mathrm{~h}$ and the chromatogram (fig. 4A) showed that one degraded product was found at a retention time of $8.6 \mathrm{~min}$. Then, $0.1 \mathrm{~N} \mathrm{HCl}$ solution was used at $80^{\circ} \mathrm{C}$ for $2 \mathrm{hr}$ and the chromatogram (fig. 4B) indicated that the drug was stable. The other study involved the use of $30 \% \mathrm{H}_{2} \mathrm{O}_{2}$ for $30 \mathrm{~min}$. and the chromatogram (fig. 4C) showed that two degraded products were found at a retention time of 4.34 and 5.95 min. Finally, water was used at $80^{\circ} \mathrm{C}$ for $2 \mathrm{hr}$ and the chromatogram (fig. 4D) showed that intensity of the peak was decreased due to degradation of the drug. The results of forced degradation studies indicated that the drug was stable in acidic condition and degraded in basic, oxidative and hydrolytic conditions. 
The presently developed method represents the first report for stability indicating HPLC assay of this drug and results of the method validation were found within acceptance criteria. However, the existing bioanalytical methods $[7,8]$ do not have forced degradation studies, utilizing sophisticated instruments and expensive methods.

\section{CONCLUSION}

The present study represents a first stability-indicating HPLC assay method that deals with the estimation of midodrine hydrochloride in tablets. The method was successfully validated as per ICH guidelines Q2 (R1). Results of stress testing study revealed that the method is stability indicating. It can be concluded from the results that the developed method is simple, rapid, accurate, specific, sensitive and precise. Thus, this method can be used for routine analysis of midodrine hydrochloride formulation and to check the stability of bulk samples.

\section{ACKNOWLEDGEMENT}

Authors thank Principal, Sinhgad College of Pharmacy, Pune for providing required facility to complete this project.

\section{CONFLICT OF INTERESTS}

Declared none

\section{REFERENCES}

1. United States Pharmacopoeia-35. National Formulary-30. Vol. 36. Pharmacopeial forum; 2012. p. 414, 3922.

2. Drug bank. Available from: http://www.drugbank.ca/ drugs/DB00211. [Last accessed on 11 Jun 2016].

3. Ghante MR, Tate AU. Development and validation of UV spectrophotometric methods for estimation of midodrine hydrochloride in bulk and tablet dosage forms. Inventi Rapid 2015;3:1-5.

4. Jain PS, Bhadane PV, Chaudhari HP, Surana SJ. Area under curve method development and validation of midodrine hydrochloride. Int J Pharm Chem Anal 2015;2:154-60.

5. Elzanfaly ES, Zaazaa HE, Merey HA. Ion selective phosphotungstate and $\beta$-cyclodextrin based membrane electrodes of stability-indicating determination of midodrine hydrochoride. Acta Chim Slov 2013;60:256-62.

6. Barth T, Aleu J, Pupo M, Bonato P, Collado I. HPLC analysis of midodrine and desglymidodrine in culture medium: evaluation of static and shaken condition on the biotransformation by fungi. J Chrom Sci 2013;51:460-7.

7. Yoshida H, Ohno Y, Yoshikuni $\mathrm{K}$, Todoroki $\mathrm{K}$, Nohta $\mathrm{H}$, Yamaguchi $\mathrm{M}$, et al. Determination of midodrine in human plasma by high-performance liquid chromatography with fluorescence detection. Anal Sci 2003;19:317-9.

8. Ahemad AA, Medhat AA, Samar F, Mohamed AK. Development and validation of LC-MSMS assay for the determination of the prodrug midodrine and its active metabolite desglymidodrine in plasma of ascitic patients: application to individualized therapy and comparative pharmacokinetics. J Chromatogr B Anal Technol Biomed Life Sci 2015;991:34-40.

9. Ranjale AR, Jain HK. Development and validation of RP-HPLC method for simultaneous estimation of cefoperazone and tazobactum in the marketed formulation. Int J Pharm Pharm Sci 2014;6:462-5.

10. Akram M, Didamony EL, Hafeez S, Saad A. Extraction spectrophotometric determination of some antihypertensive drugs in pharmaceuticals and biological fluids using two sulphonphthalein dyes. Int J Appl Pharm 2015;7:10-7.

11. Senthilraja M, Giriraj P. Reverse phase HPLC method for the simultaneous estimation of terbutanile sulphate, bromhexine HCL and guaifesin in cough syrup. Asian J Pharm Clin Res 2011;4:652-6.

12. ICH Q2 (R1), Validation of analytical procedure methodology, International Conference on Harmonization, Geneva; 2005.

13. Alagammal M, Tresina P, Mohan V. GC-MS determination of bioactive components of polygalajavana. Int J Curr Pharm Res 2012;4:162-5.

14. Gupta Y, Shrivastava A. Isocratic RP-HPLC-UV method development and validation for the simultaneous estimation of ramipril and telmisartan in tablet dosage form. Asian J Pharm Clin Res 2009:2:223-6.

15. ICH Q1A (R2), Stability testing of new drug substances and products, text and methodology. International conference on harmonization, Geneva; 2003.

\section{How to cite this article}

- Hemant K Jain, Kishor N Gujar, Varsha A Randhe. Stability indicating RP-HPLC assay method for estimation of midodrine hydrochloride in bulk and tablets. Int J Pharm Pharm Sci 2016;8(9):283-287. 